\section{Tofacitinib in refractory adult-onset Still's disease: 14 cases from a single centre in China}

Adult-onset Still's disease (AOSD) is an autoinflammatory disease characterised by spiking fever, rash, polyarthralgia, sore throat and even life-threatening complications, such as macrophage activation syndrome and fulminant hepatitis. Excessive and inappropriate production of cytokines is a cornerstone in AOSD pathogenesis. ${ }^{1}$ Unlike anakinra and tocilizumab, Janus kinases (JAK) inhibitors block the proinflammatory effect of a wide range of cytokines. This range of activity could be beneficial in AOSD patients who are refractory to or intolerant of treatment with biologicals. Anti-interleukin 1 (IL-1) agents are not available in mainland China. Tofacitinib, a JAK1/3 inhibitor, has been proven efficacious in several inflammatory diseases, such as rheumatoid arthritis, systemic lupus erythematosus and psoriasis arthritis. ${ }^{2}$ To our interest, a case report observed that tofacitinib could ameliorate arthritis in a 13 -year-old girl with recalcitrant systemic juvenile idiopathic arthritis, ${ }^{3}$ which is the juvenile counterpart of AOSD. ${ }^{4}$ Moreover, a JAK1/2 inhibitor, baricitinib has been reported effective in a 43 -year-old patient with refractory AOSD. ${ }^{5}$ Therefore, JAK inhibitors may be a novel therapeutic approach for refractory AOSD.

In our study, we aim to describe, to our knowledge for the first time, the efficacy of tofacitinib in 14 patients with refractory AOSD. All patients fulfilled Yamaguchi's criteria and were classified as refractory AOSD as defined previously. ${ }^{6}$ They were followed up for the shortest of 1 month and the longest for 24 months by the same medical team. The evaluation of tofacitinib treatment was conducted at each visit, including clinical manifestations, laboratory tests, including white cell count (WBC) count, neutrophil per cent, erythrocyte sedimentation rate (ESR), C-reactive protein (CRP) and ferritin, as well as glucocorticoids dosage adjustment. The AOSD disease activity was measured by a modified Pouchot's systemic score, ${ }^{7}$ and adverse events were also recorded. The effectiveness of treatment was defined previously ${ }^{8}$ : effective treatment was considered when all

Table 1 Baseline information of the AOSD patients at enrolment

\begin{tabular}{|c|c|c|c|c|c|c|c|c|c|c|c|}
\hline No. & G & Age & $\begin{array}{l}\text { Disease } \\
\text { duration } \\
\text { (months) }\end{array}$ & Clinical manifestations & $\begin{array}{l}\text { Previous } \\
\text { treatments }\end{array}$ & $\begin{array}{l}\text { Treatments before } \\
\text { JAKi initiation }\end{array}$ & Treatments after enrolment & $\begin{array}{l}\text { Follow-up } \\
\text { (months) }\end{array}$ & Clinical evaluation & $\begin{array}{l}\text { CR time } \\
\text { with JAKi } \\
\text { (months) }\end{array}$ & $\begin{array}{l}\text { Present } \\
\text { pred } \\
\text { dose } \\
\text { (mg/day) }\end{array}$ \\
\hline 1 & $\mathrm{~F}$ & 33 & 12 & Polyarthritis, rash & $\begin{array}{l}\text { CTX, MTX, } \\
\text { CSA, NSAIDs } \\
\text { iguratimod, } \\
\text { thalidomide, }\end{array}$ & Pred $40 \mathrm{mg}+$ tocilizumab & $\begin{array}{l}\text { Pred } 40 \mathrm{mg}+\mathrm{JAKi} 5 \mathrm{mg} \text { two times } \\
\text { per day }\end{array}$ & 24 & Effective & 16 & 2.5 \\
\hline 2 & $\mathrm{~F}$ & 27 & 6 & Fever, polyarthritis & 1 & Pred $60 \mathrm{mg}+\mathrm{MTX}+\mathrm{CsA}$ & $\begin{array}{l}\text { Pred } 60 \mathrm{mg}+\mathrm{MTX}+\mathrm{JAKi} 5 \mathrm{mg} \text { two } \\
\text { times per day }\end{array}$ & 13 & Effective & 5 & 5 \\
\hline 3 & $\mathrm{~F}$ & 32 & 48 & $\begin{array}{l}\text { Fever, rash, sore throat, } \\
\text { myalgia }\end{array}$ & Thalidomide & Pred $30 \mathrm{mg}+\mathrm{CsA}+\mathrm{HCQ}$ & $\begin{array}{l}\text { Pred } 50 \mathrm{mg}+\mathrm{HCQ}+\mathrm{JAKi} 5 \mathrm{mg} \text { two } \\
\text { times per day }\end{array}$ & 12 & Effective & 7 & 5 \\
\hline 4 & $\mathrm{~F}$ & 58 & 24 & Polyarthritis, rash & Tocilizumab & $\begin{array}{l}\text { Pred } 10 \\
m g+M T X+H C Q+C s A\end{array}$ & $\begin{array}{l}\text { Pred } 15 \mathrm{mg}+\mathrm{MTX}+\mathrm{HCQ} \\
+ \text { +JAKi } 5 \mathrm{mg} \text { two times per day }\end{array}$ & 6 & $\begin{array}{l}\text { Relapse when the pred } \\
\text { dose was reduced to } \\
2.5 \mathrm{mg} / \text { day }\end{array}$ & 1 & 1 \\
\hline 5 & $\mathrm{~F}$ & 35 & 24 & Polyarthritis, rash & $\begin{array}{l}\text { Tocilizumab, } \\
\text { thalidomide }\end{array}$ & $\begin{array}{l}\text { Pred } 10 \\
m g+M T X+H C Q+L E F\end{array}$ & $\begin{array}{l}\text { Pred } 15 \mathrm{mg}+\mathrm{MTX} \\
\text { +JAKi } 5 \mathrm{mg} \text { two times per day }\end{array}$ & 1 & Partially effective & I & 1 \\
\hline 6 & $\mathrm{~F}$ & 29 & 10 & $\begin{array}{l}\text { Polyarthritis, early } \\
\text { joint destruction, } \\
\text { lymphnodemegaly, MAS }\end{array}$ & I & Pred $100 \mathrm{mg}+\mathrm{MTX}$ & $\begin{array}{l}\text { Pred } 60 \mathrm{mg}+\mathrm{MTX} \\
\text { +JAKi } 5 \mathrm{mg} \text { two times per day }\end{array}$ & 9 & Effective & 6 & 7.5 \\
\hline 7 & $\mathrm{~F}$ & 72 & 5 & $\mathrm{ESR} \uparrow$ & I & Pred $30 \mathrm{mg}+\mathrm{HCQ}$ & $\begin{array}{l}\text { Pred } 25 \mathrm{mg}+\mathrm{HCQ}+\text { JAKi } 5 \mathrm{mg} \text { one } \\
\text { time per day }\end{array}$ & 9 & Effective & 3 & 5 \\
\hline 8 & $\mathrm{~F}$ & 25 & 19 & Polyarthritis & $\mathrm{CsA}, \mathrm{HCQ}$ & Pred $50 \mathrm{mg}+\mathrm{MTX}$ & $\begin{array}{l}\text { Pred } 50 \mathrm{mg}+\mathrm{MTX} \\
+ \text { +JAKi } 5 \mathrm{mg} \text { two times per day }\end{array}$ & 4 & Partially effective & I & 15 \\
\hline 9 & $\mathrm{~F}$ & 41 & 60 & Polyarthritis & 1 & Pred 120 mg+MTX+NSAIDs & $\begin{array}{l}\text { Pred } 60 \mathrm{mg}+\mathrm{MTX}+\mathrm{JAKi} 5 \mathrm{mg} \text { two } \\
\text { times per day }\end{array}$ & 5 & Partially effective & 1 & 1 \\
\hline 10 & $\mathrm{~F}$ & 31 & 12 & Polyarthritis & I & $\begin{array}{l}\text { Pred } 20 \\
m g+M T X+H C Q+C s A\end{array}$ & $\begin{array}{l}\text { Pred } 20 \mathrm{mg}+\mathrm{MTX}+\mathrm{HCQ}+\mathrm{Cs} \mathrm{A} \\
+ \text { +JAKi } 5 \mathrm{mg} \text { one time per day }\end{array}$ & 4 & Effective & 4 & 5 \\
\hline 11 & $\mathrm{~F}$ & 33 & 1 & $\begin{array}{l}\text { Fever, rash, sore throat, } \\
\text { polyarthritis, myalgia }\end{array}$ & 1 & Pred $60 \mathrm{mg}+\mathrm{MTX}+\mathrm{HCQ}$ & $\begin{array}{l}\text { Pred } 40 \mathrm{mg}+\mathrm{MTX}+\mathrm{HCQ} \\
+ \text { JAKi } 5 \mathrm{mg} \text { two times per day }\end{array}$ & 3 & Effective & 2 & 20 \\
\hline 12 & M & 35 & 4 & MAS & VP16, DX & Pred $25 \mathrm{mg}+\mathrm{Cs} A+$ anakinra & $\begin{array}{l}\text { Pred } 22.5 \mathrm{mg}+\mathrm{CsA}+\text { anakinra } \\
+ \text { +JAKi } 5 \mathrm{mg} \text { two times per day }\end{array}$ & 1 & Partially effective & I & 17.5 \\
\hline 13 & M & 18 & 22 & Polyarthritis, rash & I & Pred $20 \mathrm{mg}+\mathrm{MTX}$ & $\begin{array}{l}\text { Pred } 15 \mathrm{mg}+\mathrm{HCQ}+\mathrm{JAKi} 5 \mathrm{mg} \text { two } \\
\text { times per day }\end{array}$ & 1 & Partially effective & I & 10 \\
\hline 14 & $\mathrm{~F}$ & 18 & 10 & MAS, polyarthritis, rash & NSAIDs, IVIG & $\begin{array}{l}\text { Pred } 50 \\
\mathrm{mg}+\mathrm{CsA}+\text { tocilizumab }\end{array}$ & $\begin{array}{l}\text { Pred } 50 \mathrm{mg}+\mathrm{Cs} A+\mathrm{MTX} \\
+ \text { +JAKi } 5 \mathrm{mg} \text { two times per day }\end{array}$ & 1 & Partially effective & I & 35 \\
\hline
\end{tabular}

CR, complete remission; CSA, cyclosporine; CTX, cyclophosphamide; DX, dexamethasone; ESR, erythrocyte sedimentation rate; F, female; G, gender; HCQ, hydroxychloroquine; IVIG, intravenous immunoglobulin; JAK, Janus kinases; JAKi, JAK inhibitor, tofacitinib; LEF, leflunomide; M, male; MAS, macrophage activation syndrome; MTX, methotrexate; NSAIDs, non-steroidal anti-inflammatory drugs; Pred, prednisone; VP16, etoposide. 

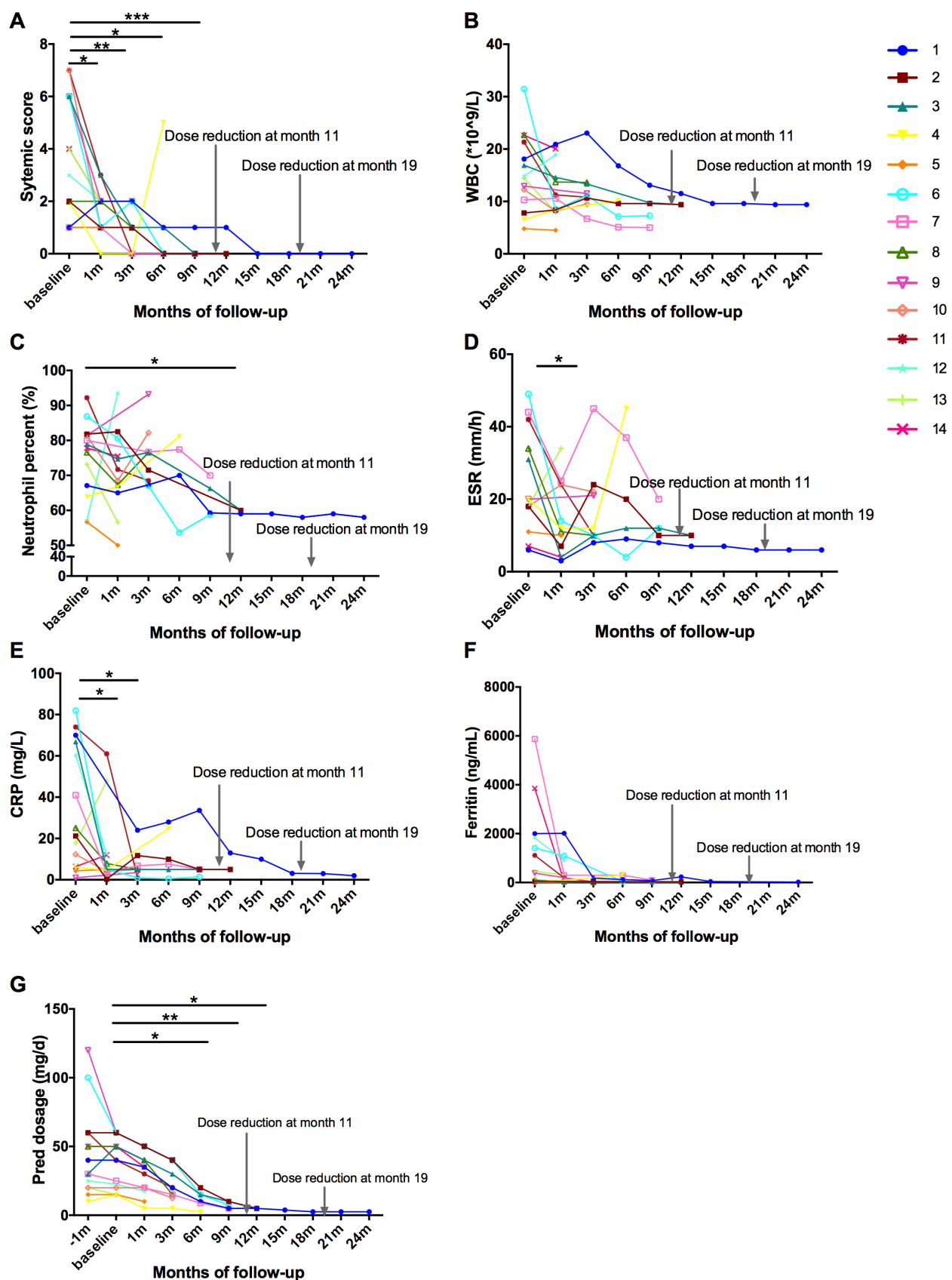

Figure 1 Contribution of improving systemic inflammation and sparing glucocorticoid dose with tofacitinib therapy. (A) Changes in systemic score in adult-onset Still's disease patients from baseline. (B-F) White cell count (WBC) count, neutrophil per cent, erythrocyte sedimentation rate (ESR), CRP levels and ferritin levels from baseline. (G) Glucocorticoid-sparing effects of tofacitinib administration. All data were statistically analysed using SPSS V.23.0. ${ }^{*} p<0.05,{ }^{* *} p<0.01,{ }^{* * *} p<0.001$.

initial clinical manifestations and abnormal laboratory tests had resolved, meaning achieving complete remission; partially effective treatment was considered when all but one initial clinical manifestation or abnormal laboratory test had resolved, meaning achieving partial remission; ineffective treatment was considered when two or more clinical manifestations or abnormal laboratory tests persisted.

The demographic data and clinical characteristics of the 14 patients are detailed in table 1 . Seven of $14(50 \%)$ AOSD patients achieved complete remission with decreased prednisone, six patients achieved partial remission and one relapsed when reduced the dosage of prednisone to $2.5 \mathrm{mg} /$ day (table 1). Totally, four patients terminated tofacitinib: two patients were for partial remission, one for menometrorrhagia and one for relapse. Two patients reduced the dosage of tofacitinib to $5 \mathrm{mg} /$ day and no relapses were observed after the adjustment. After application of tofacitinib for 1 month, seven patients quickly achieved complete resolution of fever and rashes, eight of polyarthritis. The systemic score was quickly reduced after 1 month, and completely improved at month 9 (figure 1A). WBC, neutrophil per cent, ESR, CRP and ferritin were decreased (figure 1B-F). The average dose of prednisone was significantly decreased from $37.3 \mathrm{mg} /$ day to $5.0 \mathrm{mg} /$ day at month 12 (figure $1 \mathrm{G}$ ). Adverse events occurred in two patients. One had diarrhoea and increased heart rate and the other had menometrorrhagia. The first one continued the therapy, and the second stopped tofacitinib when achieved complete remission. 
The cytokine storm activated by neutrophils and macrophages is strongly implicated in AOSD pathogenesis. ${ }^{1}$ Tofacitibib inhibits the effect of IL-6, IL-10, IFN- $\gamma$, INF- $\alpha$ and granulocyte macrophage-colony stimulating factor (GM-CSF), thus suppressing neutrophils NOD-like receptor family pyrin domain-containing 3 (NLRP3) activation and IL-1 $\beta$ production. ${ }^{9}$ Tofacitinib also suppresses macrophage activation and function. ${ }^{10}$ It provides some experimental evidence to use tofacitinib in refractory AOSD.

In conclusion, application of tofacitinib in refractory AOSD patients contributes to disease remission/revolution and sparing corticosteroid dosage, especially these with polyarthritis.

Qiongyi Hu $\odot$, Mengyan Wang, Jinchao Jia, Jialin Teng $\odot$, Huihui Chi $\odot$, Tingting Liu, Hong-lei Liu, Xiaobing Cheng, Junna Ye, Yutong Su $\odot$, Yue Sun, Zhuochao Zhou, Liyan Wan, Zhihong Wang, Fan Wang, Hui Shi, Chengde Yang $(0$

Department of Rheumatology and Immunology, Ruijin Hospital, Shanghai Jiao Tong University School of Medicine, Shanghai, China

Correspondence to Chengde Yang, Department of Rheumatology and Immunology, Ruijin Hospital, Shanghai Jiao Tong University School of Medicine, Shanghai 200025, China; yangchengde@sina.comDr Hui Shi; shihui_sjtu@sina.com

\section{Handling editor Josef S Smolen}

Contributors QH participated in follow-up, provided the figure and wrote the manuscript. MW performed statistical analysis. JJ and JT collected the clinical data at baseline. HC,TL and HL helped to prepared the table. XC, JY and Yutong Su accessed the disease activity of AOSD patients. Yue Sun, ZZ and LW analysed the data and revised the manuscript. ZW and FW helped to follow-up. HS designed, participated in follow-up and performed statistical analysis. CY designed the study, contributed to the discussion and edited the manuscript. All authors read and approved the final manuscript.

Funding This work was supported by the National Natural Science Foundation of China (81671589, 81871272, 81801602).

Competing interests None declared.

Patient and public involvement Patients and/or the public were not involved in the design or conduct or reporting or dissemination plans of this research.

\section{Patient consent for publication Obtained.}

Ethics approval The study was performed in accordance with the Declaration of Helsinki and the principles of Good Clinical Practice. Information on demographic and clinical data were obtained under a protocol approved by the Institutional Research Ethics Committee of Ruijin Hospital (ID: 2016-62), Shanghai, China. All subjects signed written informed consent.

Provenance and peer review Not commissioned; externally peer reviewed.

\section{() \\ OPEN ACCESS}

Open access This is an open access article distributed in accordance with the Creative Commons Attribution Non Commercial (CC BY-NC 4.0) license, which permits others to distribute, remix, adapt, build upon this work non-commercially, and license their derivative works on different terms, provided the original work is properly cited, appropriate credit is given, any changes made indicated, and the use is non-commercial. See: http://creativecommons.org/licenses/by-nc/4.0/.

(c) Author(s) (or their employer(s)) 2020. Re-use permitted under CC BY-NC. No commercial re-use. See rights and permissions. Published by BMJ.

$\mathrm{QH}$ and $\mathrm{MW}$ contributed equally.

\section{Check for updates}

To cite Hu Q, Wang M, Jia J, et al. Ann Rheum Dis 2020;79:842-844.
Ann Rheum Dis 2020;79:842-844. doi:10.1136/annrheumdis-2019-216699

\section{ORCID iDs}

Qiongyi Hu http://orcid.org/0000-0002-4825-5227

Jialin Teng http://orcid.org/0000-0003-1016-9064

Huihui Chi http://orcid.org/0000-0001-9587-1180

Yutong Su http://orcid.org/0000-0003-0488-2939

Chengde Yang http://orcid.org/0000-0002-3720-634X

\section{REFERENCES}

1 Hu Q, Shi H, Zeng T, et al. Increased neutrophil extracellular traps activate NLRP3 and inflammatory macrophages in adult-onset still's disease. Arthritis Res Ther 2019;21:9.

2 Jamilloux Y, El Jammal T, Vuitton L, et al. Jak inhibitors for the treatment of autoimmune and inflammatory diseases. Autoimmun Rev 2019:18:102390.

3 Huang Z, Lee PY, Yao X, et al. Tofacitinib treatment of refractory systemic juvenile idiopathic arthritis. Pediatrics 2019;143. doi:10.1542/peds.2018-2845. [Epub ahead of print: 04 Apr 2019]

4 Wang R, Li T, Ye S, et al. Application of MS score in macrophage activation syndrome patients associated with adult onset Still's disease. Ann Rheum Dis 2019:annrheumdis-2019-216286.

5 Ladhari C, Jorgensen C, Pers Y-M. Treatment of refractory adult onset still's disease with combination anakinra and baricitinib therapy. Rheumatology 2019;58:736-7.

6 Li T, Gu L, Wang X, et al. A pilot study on tocilizumab for treating refractory adultonset still's disease. Sci Rep 2017;7:13477.

7 Rau M, Schiller M, Krienke S, et al. Clinical manifestations but not cytokine profiles differentiate adult-onset still's disease and sepsis. J Rheumatol 2010;37:2369-76.

8 Vercruysse F, Barnetche T, Lazaro E, et al. Adult-Onset still's disease biological treatment strategy may depend on the phenotypic dichotomy. Arthritis Res Ther 2019:21:53.

9 Furuya MY, Asano T, Sumichika Y, et al. Tofacitinib inhibits granulocyte-macrophage colony-stimulating factor-induced NLRP3 inflammasome activation in human neutrophils. Arthritis Res Ther 2018;20:196.

10 De Vries LCS, Duarte JM, De Krijger M, et al. A JAK1 selective kinase inhibitor and tofacitinib affect macrophage activation and function. Inflamm Bowel Dis 2019;25:647-60. 